$\xi=1$ 国

\title{
Banking Inventiveness a Catalyst for Demonetization Disorder-a Study with Special Reference to New Generation Banks
}

\author{
Edmund Christopher ${ }^{1 *}$ \\ ${ }^{l}$ Dean Of Academic Affairs, ECMIT, Dubai, UAE. \\ *Corresponding Author E-Mail:Edmund@Ecmit.Ac.Ae
}

\begin{abstract}
This paper examines the contrast between the view of clients and non-clients of web saving money. The principle point of demonetization is to dampen the money subordinate economy. This article analyzed the assessment on demonetization and its belongings. This investigation utilized a quantitative approach on New Generation bank clients having pay account with this bank. Moved toward pay account holders of this bank in select universities and researched that web saving money is anything but difficult to utilize, solid, advantageous, more secure, bother free. Specialist watched that there is significant divergence amongst clients and nonclients of green preparing activities. Despite the fact that the record holders are having web managing an account office the examination enquired that they are utilizing this office for exchanges and to know the feelings for not embracing the office. This article features the significance of actuating and utilizing web managing an account to advance money less exchange. The normal outcomes may give a reasonable view to the non-clients with respect to variables to utilize web saving money. The creators utilize SPSS to investigate the supposition and mindfulness among the clients of the bank.
\end{abstract}

Keywords: Demonetization, technology banking, salary account holders, inventiveness of banks.

\section{Introduction}

The tragic effect of choice made by our regarded Prime Minister of India on money trade detonates an extraordinary change in each individual monetary life. The battle by the nationals of India has a choice to run with cashless exchanges, which is the one among the fundamental objectives behind the procedure of demonetization. Banks and money related foundations play basic obligation in supplanting the old cash to new money. The perplexity in money trade drives the general national in loads of situations. At a certain point individuals unfit to execute to fulfill the base needs too. Time turns out to be extremely stringy even to fulfill the base need of the general population.

In this development to start cashless exchanges most extreme residents occupied their hopes to green managing account techniques. At that point, the time comes to know to feature the significance of green managing an account activity. All things considered, the point of acquainting green keeping money procedures is to decrease the effect of a dangerous atmospheric division. Green managing an account is the procedure to maintain the improvement and protection of condition. Green managing an account is deciphering in two ways: one as condition amicable techniques for saving money offices and different identifies with where the bank puts the cash.

Saving money division assumes contact part between monetary improvement and environmental fortress to advance naturally manageable and societal mindful venture. The idea of green keeping money acquainted with satisfying the environmental agreeable practices of managing an account division. Banks are conveying to stay away from carbon discharges through utilization of stationery, which causes contamination in condition. Inside and remotely through client exercises managing an account part has duty to correct a few strategies to spare condition.

\section{Review of Literature}

Bihari, Suresh Chandra (2010), in his exploration article investigated the social duty of saving money area. Their demonstrated and proposed that banks have more prominent obligation in ecological harm control. Banks need to take a gander at the speculation and loaning choices and its effect on business. In business, basic leadership ecological and social criteria need to incorporate lessening the ominous effect of useful exercises. Money related establishments can perform set of endeavors to accomplish maintainability for corporate social duty.

Dharwal, Mridul, Agrwal, and Ankur (2011) in their exploration article on "green keeping the money as an imaginative activity for supportable advancement" proposed that Indian writers need to discharge books on featuring the issues of nature and societal rules in saving money areas, which is by and by banks around the world. In the event that Indian banks have needing to venture into universal markets, it is critical to perceiving their ecological and social obligations in managing an account area by starting green saving money rehearses.

Bahl, Sarita (2012), sorted out an experiential investigation on green keeping money. Their investigation involves basic methodologies took after by open division banks, which was gathered through the perspectives of supervisors working with open segment banks. Especially the examination focused on green managing an account technique embraced by banks, carbon outflow by paperless exchanges by vitality awareness, by mass 
transportation framework, by green building and social duty administrations. Their finding uncovered that among all green saving money procedures, green structures had been given best need and found that Indian banks can expand social obligation benefits by expanding green keeping money techniques.

Amitabh Misra, B. R. Kumar and Dharambir Singh (2013), in their article titled "an investigation of holes in benefit quality at a loaning private division business banks in Noida" analyzed the significance of innovation and the examination uncovers the powerless regions of the administrations of the bank, which can assist the bank specialists with overcoming the issues prompts brings down the notoriety for being admirable as to execute the means taken by them to enhance better green practices.

\section{Objectives of the Study}

- To characterize different methodologies for receiving green managing an account techniques amid demonetization period

- To look at the affecting elements to pick green saving money techniques amid demonetization period

- To analyze the effect of green saving money techniques in the supportability of New Generation Bank clients

\section{Hypothesis}

- There is no adoptability distinction in green saving money techniques amid demonetization.

- There is no critical contrast between reception of green keeping money systems in pre clients and post clients of demonetization period

- There is no effect of green managing account techniques in the manageability of New Generation Bank clients

\section{Research Methodology}

For this examination, embraced stratified arbitrary testing method, where the strata are to be considered as salaried record holders from various branches of New Generation Banks in Kerala. For this study AXIS, HDFC, ICICI bank customers. The entire state is divided in to three regions like north south and middle. Based on the population and number of branches stratified propionate sampling is applied. The overview focused on 350 people and the data gathered to distinguish the affecting components to pick green keeping money systems and to know the effect of demonetization in expanded familiarity with green managing account activities. Add up to 420 surveys were conveyed face to face to different compensation account holders in the three regions. The greatest number of investment accounts is straightforwardly aligned with instructive organizations in the investigation territory. Add up to 384 polls returned back. Barring the fragmented surveys specialist thought about 350 polls for examination.

The examination thought about the feelings of people after demonetization. Table 1 shows the awareness on green banking practices; Table 2 reveals the view of the ATM users, Table 3 express the users of internet banking, Table 4 indicate the users of mobile banking, Table 5 express the users of different services before and after the demonization and Table 6 shows the influencing factors to adopt green banking practices.

\section{Data Analysis}

Table 1: Awareness on Green Banking Practices

\begin{tabular}{|l|l|l|l|l|}
\hline Specification & Male & Female & Total & Percentage \\
\hline Have awareness & 133 & 84 & 217 & $62 \%$ \\
\hline No awareness & 79 & 54 & 133 & $38 \%$ \\
\hline Total & 212 & 138 & 350 & $100 \%$ \\
\hline
\end{tabular}

Table 2: Reveals the View of the ATM Users

\begin{tabular}{|c|c|c|c|c|c|c|c|c|}
\hline & \multicolumn{3}{|c|}{ After Demonetization } & \multicolumn{3}{c|}{ Before Demonetization } \\
\hline $\begin{array}{c}\text { Specificati } \\
\text { on }\end{array}$ & Male & $\begin{array}{c}\text { Femal } \\
\mathrm{e}\end{array}$ & $\begin{array}{c}\text { Tota } \\
1\end{array}$ & $\%$ & $\begin{array}{c}\text { Mal } \\
\mathrm{e}\end{array}$ & $\begin{array}{c}\text { Femal } \\
\mathrm{e}\end{array}$ & $\begin{array}{c}\text { Tota } \\
1\end{array}$ & $\%$ \\
\hline User & 212 & 126 & 338 & $\begin{array}{c}96 . \\
5\end{array}$ & 189 & 89 & 278 & $\begin{array}{c}79 . \\
4\end{array}$ \\
\hline $\begin{array}{c}\text { Non- } \\
\text { User }\end{array}$ & 0 & 12 & 12 & 3.5 & 23 & 49 & 72 & $\begin{array}{c}20 . \\
6\end{array}$ \\
\hline Total & 212 & 138 & 350 & 100 & 212 & 138 & 350 & 100 \\
\hline
\end{tabular}

Table 3: Express the Users of Internet Banking

\begin{tabular}{|c|c|c|c|c|c|c|c|c|}
\hline & \multicolumn{3}{|c|}{ After Demonetization } & \multicolumn{3}{c|}{ Before Demonetization } \\
\hline $\begin{array}{c}\text { Specificat } \\
\text { ion }\end{array}$ & Male & $\begin{array}{c}\text { Femal } \\
\mathrm{e}\end{array}$ & $\begin{array}{c}\text { Tota } \\
1\end{array}$ & $\%$ & $\begin{array}{c}\text { Mal } \\
\mathrm{e}\end{array}$ & $\begin{array}{c}\text { Femal } \\
\mathrm{e}\end{array}$ & $\begin{array}{c}\text { Tota } \\
1\end{array}$ & $\%$ \\
\hline User & 146 & 95 & 241 & 69 & 73 & 74 & 147 & 42 \\
\hline $\begin{array}{c}\text { Non- } \\
\text { User }\end{array}$ & 66 & 43 & 109 & 31 & 139 & 64 & 203 & 58 \\
\hline Total & 212 & 138 & 350 & $\begin{array}{c}10 \\
0\end{array}$ & 212 & 138 & 350 & $\begin{array}{c}10 \\
0\end{array}$ \\
\hline
\end{tabular}

Table 4: Indicate the Users of Mobile Banking

\begin{tabular}{|c|c|c|c|c|c|c|c|c|}
\hline & \multicolumn{3}{|c|}{ After Demonetization } & \multicolumn{3}{|c|}{ Before Demonetization } \\
\hline $\begin{array}{c}\text { Specificat } \\
\text { ion }\end{array}$ & Male & $\begin{array}{c}\text { Femal } \\
\mathrm{e}\end{array}$ & $\begin{array}{c}\text { Tota } \\
1\end{array}$ & $\%$ & $\begin{array}{c}\text { Mal } \\
\mathrm{e}\end{array}$ & $\begin{array}{c}\text { Femal } \\
\mathrm{e}\end{array}$ & $\begin{array}{c}\text { Tota } \\
1\end{array}$ & $\%$ \\
\hline User & 103 & 42 & 145 & $\begin{array}{c}41 . \\
3\end{array}$ & 67 & 31 & 98 & 28 \\
\hline Non-User & 109 & 96 & 205 & $\begin{array}{c}58 . \\
7\end{array}$ & 145 & 107 & 252 & 72 \\
\hline Total & 212 & 138 & 350 & 100 & 212 & 138 & 350 & $\begin{array}{c}10 \\
0\end{array}$ \\
\hline
\end{tabular}

Table 5: Express the Users of Different Services before and after the Demonization

\begin{tabular}{|c|c|c|c|c|c|c|c|c|}
\hline & \multicolumn{4}{|c|}{ After Demonetization } & \multicolumn{3}{c|}{ Before Demonetization } \\
\hline $\begin{array}{c}\text { Specificati } \\
\text { on }\end{array}$ & Male & $\begin{array}{c}\text { Femal } \\
\mathrm{e}\end{array}$ & $\begin{array}{c}\text { Tota } \\
1\end{array}$ & $\%$ & $\begin{array}{c}\text { Mal } \\
\mathrm{e}\end{array}$ & $\begin{array}{c}\text { Femal } \\
\mathrm{e}\end{array}$ & $\begin{array}{c}\text { Tota } \\
1\end{array}$ & $\%$ \\
\hline User & 125 & 57 & 182 & 52 & 84 & 28 & 112 & 32 \\
\hline $\begin{array}{c}\text { Non- } \\
\text { User }\end{array}$ & 87 & 81 & 168 & 48 & 128 & 110 & 238 & 68 \\
\hline Total & 212 & 138 & 350 & $\begin{array}{c}10 \\
0\end{array}$ & 212 & 138 & 350 & $\begin{array}{c}10 \\
0\end{array}$ \\
\hline
\end{tabular}

Table 6: Influencing Factors to Adopt Green Banking Practices

\begin{tabular}{|c|c|c|c|c|c|c|}
\hline \multicolumn{7}{|c|}{ Test Statistics } \\
\hline & \begin{tabular}{|c} 
Easy \\
and \\
Conveni \\
ent to \\
Use
\end{tabular} & $\begin{array}{l}\text { Hassle } \\
\text { Free }\end{array}$ & $\begin{array}{l}\text { Time } \\
\text { Saving }\end{array}$ & $\begin{array}{c}\text { Availabilit } \\
\mathrm{y} \text { of } \\
\text { Internet } \\
\text { Connectio } \\
\mathrm{n}\end{array}$ & $\begin{array}{c}\text { Quick } \\
\text { Access }\end{array}$ & $\begin{array}{c}\text { Cost } \\
\text { Affective }\end{array}$ \\
\hline $\begin{array}{c}\text { Mann- } \\
\text { Whitney U }\end{array}$ & 127.500 & 184.500 & 81.500 & 469.500 & $\begin{array}{c}248.00 \\
0\end{array}$ & $\begin{array}{c}495.00 \\
0\end{array}$ \\
\hline $\begin{array}{c}\text { Wilcoxon } \\
\text { W }\end{array}$ & $\begin{array}{c}3287.50 \\
0\end{array}$ & $\begin{array}{c}3344.50 \\
0\end{array}$ & $\begin{array}{c}186.50 \\
0\end{array}$ & 574.500 & $\begin{array}{c}153.00 \\
0\end{array}$ & $\begin{array}{c}600.00 \\
0\end{array}$ \\
\hline $\mathrm{Z}$ & -4.649 & -4.002 & -5.095 & -0.912 & -4.054 & -0.667 \\
\hline $\begin{array}{l}\text { Asymp. } \\
\text { Sig. } \\
\text { (2-Tailed) }\end{array}$ & 0.000 & 0.000 & 0.000 & 0.362 & 0.000 & 0.505 \\
\hline
\end{tabular}

Mann Whitney-Wilcoxon result shows the difference of perception to adopt green banking initiatives between pre users and post users.

The test measurement comes about show that there is a huge contrast between pre clients and post clients of green saving money activities as far as simple and helpful to work, bother free, efficient and snappy access among New Generation Bank salaried record holders.

In the event of accessibility of web association and cost adequacy, there is no noteworthy contrast between the recognitions to 
receive green managing account systems. With this examination, we can presume that over every one of the components bother free, simple and advantageous utilize, brisk access and efficient are the all the more impacting factors notwithstanding the accessibility of good web association and cost-adequacy to utilize. Table 7 represent the effect of ATM, POS, RTGS, ECS, NEFT and mobile banking on the sustainability of New Generation bank customers

Table 7: Represent the Effect of ATM, POS, RTGS, ECS, NEFT and Mobile banking on the Sustainability of New Generation Bank Customers

\begin{tabular}{|c|c|c|c|c|}
\hline Model & $\mathrm{R}$ & $\begin{array}{c}\mathrm{R} \\
\text { Square }\end{array}$ & $\begin{array}{c}\text { Adjusted R } \\
\text { Square }\end{array}$ & $\begin{array}{c}\text { Std. Error of the } \\
\text { Estimate }\end{array}$ \\
\hline 1 & 0.972 & 0.916 & 0.534 & 0.38542 \\
\hline
\end{tabular}

Table 8: Reveals the Relationship between Green Banking Strategies and Sustainability of New Generation Bank Customers through ANOVA ${ }^{\mathrm{a}}$

\begin{tabular}{|c|c|c|c|c|c|c|}
\hline $\begin{array}{c}\text { Mod } \\
\text { el }\end{array}$ & $\begin{array}{c}\text { Sum of } \\
\text { Squares }\end{array}$ & df & $\begin{array}{c}\text { Mean } \\
\text { Squa } \\
\text { re }\end{array}$ & F & Sig. & \\
\hline \multirow{4}{*}{1} & $\begin{array}{c}\text { Regressi } \\
\text { on }\end{array}$ & $\begin{array}{c}21.07 \\
7\end{array}$ & 9 & $\begin{array}{c}2.34 \\
2\end{array}$ & $\begin{array}{c}13.18 \\
8\end{array}$ & $\begin{array}{c}0.00 \\
0^{\mathrm{b}}\end{array}$ \\
\cline { 2 - 7 } & Residual & $\begin{array}{c}60.37 \\
7\end{array}$ & 340 & $\begin{array}{c}0.17 \\
8\end{array}$ & & \\
\cline { 2 - 7 } & Total & $\begin{array}{c}81.45 \\
4\end{array}$ & 349 & & & \\
\hline
\end{tabular}

Form the above Table 8 represents $\mathrm{R}=0.972$, $\mathrm{R}$ square value is 0.916 and adjusted $\mathrm{R}$ square is 0.534 . This shows the variance ranges from 97.2 to 91.6 and between green banking strategies and sustainability of New Generation bank customers

Table 9: Shows the Coefficient

\begin{tabular}{|l|c|c|c|c|c|}
\hline \multirow{2}{*}{ Model } & \multicolumn{6}{|c|}{$\begin{array}{c}\text { Unstandardized } \\
\text { Coefficients }\end{array}$} & $\begin{array}{c}\text { Standardized } \\
\text { Coefficients }\end{array}$ & \multirow{2}{*}{ Sig. } & \\
\cline { 2 - 4 } & $\mathrm{B}$ & $\begin{array}{c}\text { Std. } \\
\text { Error }\end{array}$ & Beta & & \\
\hline ECS & 1.449 & 0.075 & 0.962 & 4.219 & 0.000 \\
\hline $\begin{array}{l}\text { Mobile } \\
\text { banking }\end{array}$ & 0.390 & 0.124 & 0.804 & 3.146 & 0.002 \\
\hline NEFT & 0.166 & 0.049 & 0.779 & 3.381 & 0.001 \\
\hline RTGS & 0.165 & 0.088 & 0.734 & 2.890 & 0.040 \\
\hline ATM & 3.216 & 0.336 & 0.976 & 6.984 & 0.012 \\
\hline POS & 1.339 & 0.342 & 0.865 & 3.854 & 0.041 \\
\hline
\end{tabular}

From the Table 9 the ATM $(t=6.984, p=0.012)$, ECS $(t=4.219$, $\mathrm{p}=0.000)$, POS $(\mathrm{t}=3.854, \mathrm{p}=0.041)$, NEFT $(\mathrm{t}=3.381, \mathrm{p}=0.001)$, mobile banking $(\mathrm{t}=3.146, \mathrm{p}=0.002)$, and RTGS $(\mathrm{t}=2.890, \mathrm{p}=0.040)$ are statistically significant at $5 \%$. Since the t-value of ECS is more than the remaining initiatives of green banking. It is concluded that ATM play major role in sustainability of New Generation bank customers. Next to that ECS, POS facilities are used by customers to overcome demonetization chaos.

\section{Results and Discussions}

From the above examination among green managing an account activities ATM, ECS and POS are for the most part utilized by the clients of New Generation bank. They are assuming a key part in the view of clients to manage with the bank for long haul despite the fact that some perplexity like demonetization, mindfulness among these offices fulfilling the clients and helpful to save money with. In this investigation, it is watched that the expansion in utilization of green keeping money methodologies because of demonetization. Research sorted out on pay account holders, in this view tests are graduates and have the capacity to comprehend and can without much of a stretch adjust to the change.

\section{Conclusion}

After demonetization, a more noteworthy increment saw in the use of ATM, POS, and NEFT. The examination uncovers that there is no distinction of feelings in the two guys and females. From the examination a wide range of green managing account techniques have some impact on the maintainability, among them ECS; POS and ATM are having a noteworthy inclination for the clients. Consequently the green saving money strategies embraced by New Generation Bank salaried record clients making a greater significance of being paperless keeping money.

\section{References}

[1] Arun Prem KD, "A Study on Entrepreneurial Leadership Skills and Human Resource Management in Small and medium Tourism Enterprises", International Journal of Applied Business and Economic Research, Vo.15, No.6, (2017).

[2] Bahl S, "The Role of Green Banking in Sustainable Growth", International Journal of Marketing, Financial Services \& Management Research, Vol.1, No.2, (2012).

[3] Biswas N, "Sustainable green banking approach: The need of the hour", Business Spectrum, Vol.1, No.1, (2011), pp.32-38.

[4] Cris Kochukalam KD, "A Study on the Factors for Intermediary Dependence Among Decorative Paint Customers Exploring the Impact Significance", International Journal of Applied Business and Economic Research, Vol.15, No.6, (2017).

[5] CrisKochukala KD, "Problems and Challenges of Decorative Paint Customers in Paint Preference: A Study Among Decorative Paint Customers of Kerala", International Journal of Applied Business and Economic Research, Vo.15, No.6, (2017).

[6] CrisKochukalam, KD, "A Study Among Decorative Pain Customers on Factors Influencing Preference of Decorative Paint Brands", International Journal of Applied Business and Economic Research, Vol.15, No.6, (2017).

[7] CrisKochukalam. KD, "A study Explaining Branding Brand Experience Among Decorative Paint Customers", International Journal of Applied Business and Economic Research, Vo.15, No.6, (2017).

[8] Dhanya JS \& Kinslin D, "A Study on Impact of Work Life Balance on Retention of Women Teachers in Management Colleges in Kerala", International Journal of Applied Business and Economic Research, Vol.15, No.4, (2017).

[9] Dhanya JS \& Kinslin D, "A Study on Work Life Balance of Women Employees at ULCCS Ltd., Kozhikode", International Journal of Applied Business and Economic Research, Vol.15, No.4, (2017).

[10] Dhanya JS \& Kinslin D, "Clair Model for Better Work Life Balance and Empowerment of Women Faculty in Professional Colleges of Kerala", International Journal of Applied Business and Economic Research, Vol.15, No.4, (2017).

[11] Edmund Christopher S, "A Study on Buying Behaviour of Customers Towards Branded and Non-Branded Gold Jewellery with Reference to Kanyakumari District", International Journal of Management (IJM), Vol.5, No.10, (2014), pp.105-114.

[12] Edmund Christopher S, "A Whiff of IT Industry Work Stress and Accelerating the Productivity: with Special Reference to Indian IT Industry", Zenith International Journal of Business Economics and Management Research, Vol.4,(2014).

[13] Edmund Christopher S, "An Analytical Study on Service Quality of Air India with Special Reference to Southern Region", International Journal of Applied Engineering Research, Research India Publications, Vol.10, No.45, (2015), pp.32021-32024.

[14] Edmund Christopher S, "Drain the Women Entrepreneurial Effort to Manage Global Crisis is The Need of an Hour-A Focus Based on Indian Context GE", International Journal of Management Research (GE-IJMR), (2016), pp.87-97.

[15] Edmund Christopher S, "Employee Training and Development Practices in Air India-A Descriptive Glance with Reference to Chennai", International Journal of Applied Engineering Research, Research India Publications, Vol.10, No.45, (2015), pp.3200532008.

[16] Edmund Christopher S, "Performance of Air India with Special Reference to Passenger Fluctuations-A Focus", Indian Stream Research Journal, Vol.4, No.10, (2014), pp. 01-06

[17] Edmund Christopher S, "Reengineering the Process of Performance Evaluation towards the Employee's Development - Need of the Time in IT Industry", Journal of Chemical and Pharmaceutical Sciences, (2016), pp.1823-1826. 
[18] Edmund Christopher S, "Relaunching the Retailing in Small Towns: New Growth Frontiers Open Up in Rural India", International Journal of Marketing, Financial Services \& Management Research, Vol.3, No.7, (2014), pp.57-66.

[19] Farooqi, MR, Kumari S \& Shoeb M, "Recent Trend of e-CRM in Commercial Banks of India", International Journal of Application or Innovation in Engineering \& Management, Vol.2, No.4, (2013).

[20] Gurusamy S \& Vengatesan C, "Green Banking-A Conceptual framework", Kaveripakkam College Journal of Management Research, Vol.4, No.12, (2014), pp.39-46.

[21] Joshua AJ \& Koshy MP, "Usage Patterns of Electronic Banking by Urban Educated Customers: Glimpses from India”, Journal of Internet Banking and Commerce, Vol. 16, No.14, (2011).

[22] Mahdi S \& Mehrdad A, "E-Banking in Emerging Economy: Empirical Evidence of Iran", International Journal of Economics and Finance, Vol.2, No.1, (2010), pp.201-209.

[23] Saroj DKD, Asif DP \& Firoz MP, "Service Quality Measurement and its evaluation of leading Private Banks of India in Delhi and NCR Region", An analytical study International Journal of Contemporary Business Studies, Vol.4, No.1,(2013).

[24] Shaji Y \& Kinslin D, "Employee Retention Practices for Leaders A Study in Information Technology Organization", International Journal of Applied Engineering Research, Vol.10, No.45, (2015).

[25] Sharma N, Sarika K \& Gopal R, "A Study on Consumer's awareness on Green Banking Initiatives in Selected Public and Private Sector Banks with Reference to Mumbai", IOSR Journal of Economics and Finance, (2014), pp.28-35. 